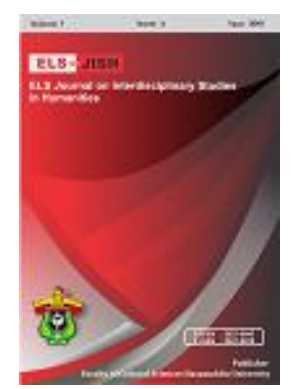

ELS-JISH

ELS Journal on Interdisciplinary Studies on Humanities

Volume 2 Issue 3, 2019

ISSN (print) : 2621-0843

ISSN (online) : 2621-0835

Homepage : http://journal.unhas.ac.id/index.php/jish

\title{
Code Mixing in Yowis Ben Film by Fajar Nugros
}

\author{
Titi Suryaningrum ${ }^{1}$, Sumarlam $^{2}$, Djatmika $^{3}$ \\ ${ }^{1}$ twetty.suni@gmail.com
}

\begin{abstract}
This research discussed code mixing in Yowis Ben film from Fajar Nugros which is 80 percent using Javanese language. This paper aims to describe forms and factors of using code mixing. This paper is a kind of descriptive qualitative using obeservation-notification method (simak catat). Data in this study are oral data which is using information form. Population are all of dialog in Yowis Ben film. The result shows there are code mixing word form, phrase, baster, word of frequent, and idiom dominantly code mixing word form from Indonesian language insert to Javanese language. Factors of using code mixing are need for synonim, Social value, development and identification of new culture, low frequency of word, pernicious homonimy, oversight, and end (purpose and goal).
\end{abstract}

Keywords: Code Mixing, Language Variety, Film

How to cite: Suryaningrum, T., Sumarlam, \& Djatmika. (2019). Code Mixing in Yowis Ben Film by Fajar Nugros. ELS Journal on Interdisciplinary Studies in Humanities, 2 (3), 355-367

\section{Introduction}

A bilingual phenomenon can occur anywhere and anytime. A person can become a bilingual at the age of both children and adults. In a bilingual situation the result is mixed code. Nababan (1991: 32) states that, when people mix (two or more) languages or various languages in an act of language without something in a language situation that demands a mixture of languages called mixed code. Code mixing is a communication event found in multicultural communities. This event occurs because the multicultural community has a variety of languages. The diversity of languages makes a person become bilingual or multilingual, which is mastering more than one language so that in communication, the two or more languages that are mastered by speakers will be mixed in a speech. Mixing these two languages or more in a communication process is what is called mixed code. Code mixing can occur anywhere, such as at school, in the home environment, on campus, in the work environment, in print media, or in electronic media. One form of electronic media, especially film.

Film is one of the communication media with audio and visual forms that is being watched by the public. The book titled Memahami Film written by Himawan Pratista there is film language. Film language are combine between audio language

${ }^{1,2}$ Sebelas Maret University, Indonesia 
and visual language. Sineas offers a solution through the film with the hope that of course it can be well received by people watching (Himawan Pratista, 2008: 3). The book titled Memahami Film by Himawan (2008: 150) written "Dialog dalam film juga tidak terlepas dari bahasa bicara yang digunakan dan dipengaruhi oleh aksen". Language speaks itself is the main language used in the whole film, language speaks depending on where the setting and time of the film being made.

The 1 hour 30 minute Yowis Ben film carries the genre of comedy drama, describing events that are so close to everyday life. The use of the Javanese language appears to be in accordance with the look of Yowis Ben's movie plot, increasingly thickening the emotional background that radiates in each scene. The intriguing words of local idioms are also contained in the dialogue, combined with the hilarious behavior of a number of figures.

As for the mixed code can be found in this film, can be copied when Bayu was breaking the piggy bank, suddenly the cellphone next to it rang, and he read the message inside. Next he showed a reaction then said to himself what he saw on the cellphone screen, saying: "wuih, emoticon Kiss!". Another example of a dialogue fragment:

Yayan

Bayu : "Jane bolos iki mau isa smoothly, rek, nek misale awakke dhewe

"Ancen bolos iku gak apik sih, rek. Sesuk aja dibaleni maneh ya."

(Indeed ditching is not good. Tomorrow do not repeat again) ga nuruti idene Doni."

(I should have skipped it before it could run smoothly if we didn't follow Doni's idea.)

\section{(175/ 00.46.17/ YWB)}

The narrative in the dialogue took place when the four of them were arguing in front of the merchandising cart outside the school, regarding the actions they carried out led to the punishment of the school principal for the trial of skipping school and being caught by the security guard.

In data number 175, there is an event that interferes with the external code in the form of the verb performed by Bayu. Code mixing occurs because of the insertion of English words smoothly which means 'dengan lembut' into Javanese speech. The word smoothly has the equivalent meaning in Javanese is mulus which is said by Javanese accent. So if the speaker's speech is converted into Javanese into "Jane bolos iki mau isa mulus, rek, nek misale awakke dhewe ga nuruti idene Doni." The factor that causes code interference is that speakers want to show that they are educated and modern.

Research that is relevant to this research is the research conducted by Denti Okta Puspita (2018), entitled Campur Kode dalam Film My Stupid Bos dan Implikasinya pada Pembelajaran Bahasa Indonesia di SMA (Mixed Code in the Film of My Stupid Bos and Its Implications for Learning Indonesian in High School). This thesis examines the forms of mixed code and the causes of code interference in the film My Stupid Bos. The results of the study show a mix of word-tangible codes, mixed tangible clause codes, mixed tangible code phrases, and repetitive tangible 
code. The disadvantage of the research is that it does not indicate the type of code mixing.

Supreme Thesis Tri Debbyansyah (2014), entitled Campur Kode Bahasa Jawa dalam Bahasa Indonesia pada Film Jokowi (The Javanese Language Code Mixing in Indonesian in the Jokowi Film). In this paper the researcher limits his research to only interfering with the Javanese language code into Indonesian. The results of the study show that there are 5 forms of mixed Javanese language code in Indonesian in Jokowi's films, which are mixed word-shaped codes, mixed code in the form of affix words, mixed code in the form of repeated words, mixed code-shaped phrases, and clause-shaped code mixes. The weakness of the research is that it is only limited to research on the type of interfering internal code specifically for the insertion of Javanese into Indonesian only.

Fuji Anjalia scientific journal (student PBSI Vol. 2 No. 2; March 2017: 142-145), entitled Analisis Campur Kode dalam Dialog Antartokoh pada Film Tjoet Nja' Dhien (Code Mixing Analysis in Inter-Political Dialogue at Tjoet Nja 'Dhien Film). In the film Tjoet Nja 'Dhien mixed 8 word-shaped code data, mixed code in the form of 7 data phrases, mixed code in the form of repetition of the word 23 data, and mixed code in the form of clauses there are 3 data. The disadvantage in the study was that there was no research on the type of code mixing.

Nurul Hudha's thesis (2018), with the title Alih Kode dan Campur Kode dalam Dialog Film Guru Bangsa Tjokroaminoto karya Gari Nugroho dan Implikasinya terhadap Pembelajaran Sosiolinguistik di Perguruan Tinggi (Code Switching and Code Mixing in the Dialogue of Film Nation Teachers Tjokroaminoto by Gari Nugroho and the Implications for Sociolinguistic Learning in Higher Education). In this thesis research explained about the transfer and code mixing consisting of internal and external code switching and mixed code used in the form of words, phrases, clauses, repetition of words and idioms. The most dominant code change in this thesis is external code switching in the form of switching Dutch code into Indonesian and the most influencing causative factors are changes in the topic of conversation. The most dominant mix of codes is mixed code in the form of words in Indonesian and the factors that most influence the occurrence of code mixing are the attitude attitudes of speakers. The disadvantage of the research is that there is no data found that shows mixed baster codes.

Of the four studies above, the author still rarely finds a thesis that takes research data on Javanese films. The author has found many theses that analyze films whose dialogue is predominantly in Indonesian because films in Indonesia generally use Indonesian which is a national language understood by most people in Indonesia. When viewed from the shortcomings of the above research, namely the absence of research on the type of external code mixing and mixed code in the form of baster, the researchers want to take a research gap to be able to complement previous research. Thus, in order to complement the previous research, the researcher took the dominant object of film research in Javanese with the aim of examining the types of internal and external codes as well as mixed forms of code.

In some Indonesian films there is also the use of regional languages but not the language of speech. The author chose Yowis Ben's film because Yowis Ben's film was a film that $80 \%$ used Malang regional language to become the language of 
speech in the film. The author sees that there are many mixed-code language variations performed by film players.

\section{Method}

The research design used in this study is qualitative research to describe the data in the form of Yowis Ben's language speeches. In this research, researcher try to explain code choice: code mixing form. The data used in this study are oral data in the form of sentence utterances or utterances of words of Yowis Ben's film players that contain mixed code. The data source is in the form of a film dialogue language. Yowis Ben's film, which was released on February 22, 2018 with a duration of 1 hour and 30 minutes, carries the genre of comedy drama, describing events that are so close to everyday life.

The data collection technique used in this study is the ability to read freely and then note the technique. Free listening technique is a technique in which the researcher only acts as a researcher, and is not involved in the conversation (Mahsun, 2005: 91). This research object of the study is Yowis Ben's film. So, the researchers listened to the dialogue conducted by the characters in the film.

Furthermore, in the process of listening, of course the researcher needs recordings in the form of notes, so further techniques are developed, namely the recording technique. The field notes used are descriptive and reflective notes. Descriptive notes are descriptions of what is listened to, seen, and thought through during the data collection process, while reflective notes are interpretations of the utterances. Moleong (2005: 235) data collection usually produces very many written records, or video / audio about conversations that contain multiple pieces of data which are later sorted and analyzed. This process of data collection can be done repeatedly watching Yowis Ben's film to get good results. The researcher transcribed all the dialogues in Yowis Ben's film and then marked the speech containing the mix and then analyzed.

\section{Findng and Discussion}

The study data in this thesis comes from the transcription of the speeches of Yowis Ben's film players. Not all speeches can be used as data because not all utterances in the data transcribed by the author have mixed code usage. Therefore, the author only analyzes speeches which are forms of mixed code.

In this study, the author found 221 data in the speeches of Yowis Ben's film players containing mixed code. 
Table 1. Research data mix code results table

\begin{tabular}{|c|c|c|c|c|c|c|c|c|}
\hline \multirow{2}{*}{$\begin{array}{c}\text { Type } \\
\text { of } \\
\text { code }\end{array}$} & \multirow[t]{2}{*}{ Code mixing } & \multicolumn{5}{|c|}{ forms } & \multirow[t]{2}{*}{ total } & \multirow{2}{*}{$\begin{array}{l}\text { Percenta } \\
\text { tion }\end{array}$} \\
\hline & & 임 & 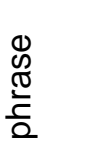 & 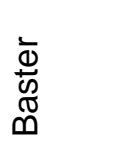 & $\begin{array}{l}\text { 정 } \\
\frac{\text { 음 }}{\text { 을 으 }} \\
\text { 잉 }\end{array}$ & 흥 & & \\
\hline \multirow{2}{*}{$\stackrel{\frac{5}{d}}{\stackrel{c}{\Xi}}$} & $\begin{array}{l}\text { Javanese- } \\
\text { Indonesian }\end{array}$ & 99 & 10 & 28 & 6 & 4 & 147 & $66,5 \%$ \\
\hline & $\begin{array}{l}\text { Indonesian- } \\
\text { Javanese }\end{array}$ & 5 & - & 2 & 1 & - & 8 & $3,6 \%$ \\
\hline \multirow{3}{*}{$\frac{\text { c }}{\frac{d}{x}}$} & $\begin{array}{c}\text { Javanese- } \\
\text { English }\end{array}$ & 29 & 9 & 7 & 1 & 1 & 47 & $21,3 \%$ \\
\hline & $\begin{array}{c}\text { Javanese- } \\
\text { Arabic }\end{array}$ & 4 & - & 1 & - & - & 5 & $2,3 \%$ \\
\hline & $\begin{array}{l}\text { Indonesia- } \\
\text { English }\end{array}$ & 2 & 4 & 5 & 3 & - & 14 & $6,3 \%$ \\
\hline & Total & 139 & 23 & 43 & 11 & 5 & 221 & $100 \%$ \\
\hline & entation & $62,9 \%$ & $10,4 \%$ & $19,5 \%$ & $4,9 \%$ & $2,3 \%$ & $100 \%$ & \\
\hline
\end{tabular}

\section{a. Internal Mixing Code}

According to Suwito (1985: 76) internal code mixing is a mix of codes that occur between regional languages in national languages, between dialects in one regional language or between several varieties and styles that have one dialect or a mixture of languages that are still closely allied.

\section{Mix Code in Word Form}

\section{1) Mix the Noun Code}

Mixed noun code is the insertion of the use of Indonesian in the form of nouns into Javanese. Nouns are the names of objects or everything that is blocked (Rohmadi, et al., 2009: 158).

\section{Bayu: "Aku njaluk saran." \\ (I ask for advice)}

(62 / 00.08.12/ YWB)

In the data above in Bayu's speech there was an event of internal code mixing in the form of nouns, namely the entry of elements of Indonesian nouns "saran" into Javanese sentences. The word "saran" has the equivalent of words in Javanese "panemu" so it would be better if Bayu's speech using the Javanese language becomes "Aku njaluk panemu." 


\section{2) Mix the Verb Code}

Mixed verb code is the insertion of the use of Indonesian in the form of a verb into Javanese sentences. Verbs are all words that express deeds or behavior (Rohmadi, et al., 2009: 158).

Bayu: "Tapi iki temenan blas ga direspon Iho, Cak Jon."

(but this really isn't responded, Cak Jon.)

(29/ 00.02.42/ YWB)

It can be seen in the data above that Bayu has interfered with the internal code in the form of Indonesian verbs "respon" to Javanese sentences. The word "respon" has the equivalent of the Javanese word "dibales". Bayu's speech will be as follows when using Javanese: " Ning iki temenan blas ga dibales Iho, Cak Jon."

\section{Mix Code in Phrase}

Mix the code in the form of phrases also occur in the dialogue of Yowis Ben movie players. The following dialog contains a code mix for one of the players.

\section{1) Mixed Noun Phrase Codes}

Mixed code for noun phrases is the mixing of Indonesian language in the form of noun phrases into other languages. Noun phrases are groups of words that state the name of an object or object.

Bayu: "Lha kon lahpa nendang sepeda motorku, Cuk?"

(Why are you kicking my bike?)

(2/ 00.00.45 / YWB)

In the data above the speakers did internal code mixing in the form of the Indonesian noun phrase "sepeda motorku" into Javanese speech. The word "sepeda motorku" has a Javanese equivalent word "pit montor" so if Bayu's speech is changed into Javanese to "Lha kon lahpa nendhang pit montorku, Cuk?"

\section{Mix the Baster-shaped Code}

\section{2) Indonesian word + suffix from Javanese}

The term baster form in this study refers to a mixture of Javanese and Indonesian languages used in Javanese sentences which are the core.

Bayu: "Huh, apa puisine sampeyan iki ancene wis gak jaman, Cak Jon?'

(Huh, your poetry is not in time, Cak Jon?)

(32 / 00.02.53 / YWB

In the data in the form of baster in the form of words of puisi derived from the Indonesian language which inserts into Javanese speech + suffix -e comes from Javanese. The word puisi has the equivalent word in Javanese, namely geguritan, so the speech of the speaker will change to " Huh, apa geguritane sampeyan iki ancene wis gak jaman, Cak Jon?"

\section{3) Prefix from Javanese + Words from Indonesian}

The form of baster in this data refers to a mixture of Indonesian and Javanese 
that is used in Indonesian speech as the core.

Bayu: "San Susan. San, pecelnya sudah takkasih ke temen kamu."

(San Susan. San, I have given the pecel to a friend you.)

(90 / 00.15 .20 / YWB)

In the data above the form of baster is in the form of prefix tak- from the Javanese language that enters Indonesian speech + the word kasih from the Indonesian language. The prefix tak- has equivalent of pronoun -ku in Indonesian. So the speech of the speaker is changed into Indonesian into "San Susan. San, pecelnya sudah kukasih ke temen kamu."

\section{Mix The Code in The Form Of Reduplication}

Mix code in the form of reduplication that occur in the speeches of Yowis Ben's film players.

Bayu: "Doni ki rada pancen. Jelas-jelas ra becus nyedhaki wedok malah nasihatin

aku."

(Doni is indeed rather. Obviously can't approach even women give me advice.)

(58 / 00.07.02 / YWB)

In the fragment of Bayu's speech above, there appears to be an event of internal code mixing in the form of reduplication. Code mixing occurs because the lexicon insertion clearly comes from the Indonesian vocabulary into Javanese speech. The lexicon clearly has a Javanese equivalent word cetha-cetha. So if the speech of the speaker is changed into Javanese into "Doni ki rada pancen. Cethacetha ra becus nyedhaki wedok malah nasihatin aku."

\section{Mix Code in the form of Idioms}

Cak Kartolo: "Jaman Majapahit wis tak sir Cuma mbakyumu jual mahal."

(On Majapahit era I have had a crush on your sister but she has

played hard to get.)

(42 / 00.03.59 / YWB)

From the data above, speakers intervene in internal code mixing in the form of idioms (expressions) because their meanings cannot be explained based on the meaning of the words that form them, namely the entry of Indonesian idioms jual mahal in Javanese sentences. The jual mahal phrase means that you don't want to say yes right away so it's not considered cheap. There is no equivalent of idiom jual mahal in Javanese language idioms but there are words that have similar meanings namely the word kemayu, kumayu which means pretentious. So if the speaker's speech is changed to a Javanese sentence, Jaman Majapahit wis tak sir Cuma mbakyumu kemayu. 


\section{b. External Codes Mixing}

According to Soewito (1985: 76), external code mixing occurs because of the insertion of elements sourced from foreign languages.

\section{Code Mixing in Word Form}

\section{1) Noun Code Mixing}

Bayu: "Wong kene ngomongke skill kok."

(We talk about their abilities)

(140/ 00.24.18/ YWB)

In the data above the speakers did external code mixing in the form of nouns from the Indonesian "skill" into Javanese speech. The word "skill" has the equivalent word in Javanese, namely "kabisan" so if the speech of the speaker is converted into Javanese into "Wong kene ngomongke kabisan kok".

And then the next data:

Papa Nando: "Papa punya surprise buat kamu."

(Papa has a surprise for you.)

(153/00.31.23/ YWB)

In the data above, there is an external code mixing in the form of an English word "surprise" that inserts into Indonesian. The word "surprise" has the equivalent meaning in Indonesian, namely kejutan. So if the speaker's speech is changed into Javanese into Papa punya kejutan buat kamu.

\section{2) Adjective Code Mixing}

Yan: "Ja su'udzon paling macet."

(Don't get worse, most suspects.)

(185/00.57.09/ YWB)

In the data above there is an external code mixing in the form of the Arabic adjective "su'udzon" which inserts into Javanese. The word "su'udzon" has the equivalent meaning in Javanese, namely "duwe pikiran ala". So if the speaker's speech is changed into Javanese into Ja duwe pikiran ala paling macet.

\section{Mix Code in Phrase}

\section{3) Mix Code Description Phrases}

Doni: "Kamera iki sing paling pas nek awakke dhewe gawe videoklip low budget."

(This camera is the most appropriate if we make video clips low budget)

(169/ 00.38.24/ YWB)

In the data above, speakers did the form of the description phrase "low budget" in the Javanese language. The phrase "low budget" means "modal kecil".

\section{Mix Baster-Shaped Codes}

\section{4) Prefix from Javanese + English words}


The term baster form in this study refers to a mixture of Javanese and English used in Javanese sentences which are the core.

Stevia: "Wis tak-screencapture wis tak-print. Lho iki arekke Iho."

(I have already downloaded it, I already print. This is the child)

(53/ 00.05.26/ YWB)

In the data in the form of baster in the form of a word print derived from English which inserts into the Javanese speech + the non-origin comes from the Javanese language. The word print has the equivalent word in Javanese, namely cithak 'cetak' so that the speaker's speech will change to Wis tak-screencapture wis takcithak. Lho iki arekke Iho.

\section{Mix the code in the form of reduplication}

Stevia: "Jadi guys Bayu wingi ngirimi aku puisi."

(So guys Bayu yesterday sent me poetry.)

(50/ 00.05.17/ YWB)

In the fragment of Bayu's speech above, there appears to be an external code mixing event in the form of reduplication. In Javanese sentences spoken by speakers there are English lexicon inserts "guys", so it can be seen that speakers intervene in the external code in the form of repetitive words because in English the additional letter "-s" behind the word makes the word plural.

\section{Mix Code in the form of Idioms}

Yan: "Btw ana sing ngomong aku nggatheng gak?'

(By the way someone says I'm handsome no?)

(190/ 01.00.47/ YWB)

From the data above, speakers did external codes mixing in the form of idioms (expressions) because their meanings cannot be explained based on the meaning of the words that form them, namely the inclusion of English idioms by their length by the way in Javanese sentences. The phrase by the way means by the way. There is no equivalent idiom by the way in Javanese idioms.

\section{c. Factors that Cause the Code Mixing}

Factors that caused the code mixing in Yowis Ben's film, as follows.

\section{Need for synonim}

Speech Context:

Bayu was angry with his motorcycle which broke down, then kicked his own motorbike. Kamidi kicked Bayu's motorbike without knowing the cause of Bayu's anger at his motorcycle. Bayu was disturbed by Kamidi's actions. Kamidi feels guilty then apologizes.

Speech:

Kamidi: "Sorry ya tak kira iki jahat." 
(Sorry, I think this is evil)

(13/ 00.01.29/ YWB)

The code mixing that Kamidi does is an external mix of tangible words. Kamidi did code mixing intending to refine his speech, namely Kamidi intending to apologize to Bayu because he joined in kicking Bayu's motorcycle without cause.

\section{Social value}

Speech Context:

Stevia spoke in front of the class to show that she was sent a poem by Bayu. From the style of uniforms and makeup, Stevia is a popular kid at school.

Speech:

Stevia: "Jadi guys Bayu wingi ngirimi aku puisi."

(So guys Bayu yesterday sent me poetry)

(50/ 00.05.17/ YWB)

Speeches on data (50) contain external code interfering events in the form of word repetitions performed by speakers. Speakers interfered with the code because the speaker wanted to show that he was educated and modern and slang by showing a new style / language style in communication that was seen in the words guys used.

\section{Development and introduction of new cultures}

Speech Context:

Bayu, Doni, and Yan were surprised and strange to see Nando avoid being approached by girls.

Speech:

Yan: "Iku dudu khilaf tapi kelebon jin."

(It doesn't make mistakes but concedes genie)

(127/ 00.22.11/ YWB)

According to Masinambouw (1997) that language and culture are two systems inherent in humans. Culture is a system that regulates human interaction in society, while language is a system that functions as a means of ongoing interaction. Relationship between language and culture such as two sides of a coin, one side as a language system and the other as a cultural system.

The development of Islam in Indonesia today leads to the absorption of terms from Arabic into Indonesian as seen in data 127, namely the insertion of Arabic into Javanese speech. On the cultural aspect, Arabic also has a large role in the development of Indonesian culture such as the use of children's names from Arabic such as Ahmad is the name of the Arabic language which means very praiseworthy. In addition, Arabic terms are also used in the daily language of Muslims in Indonesia such as, bismillah, astaghfirullah, alhamdulillah, and so on.

\section{Low frequency of word}

\section{Speech Context:}


Bayu's mother was angry because Bayu asked for a discount on pecel prices for Susan's order.

Speech:

Ibu Bayu: "Diskon apa? Modal seket ewu njaluk diskon."

(What discount? Capital fifty thousand asking for a discount.)

(81/ 0010.58/ YWB)

At 81 utterances, the insertion of a discounted Indonesian word into Javanese speech is seen. The word dikon is actually an adaptation of the discounted English vocabulary. The word discount has the equivalent word in Javanese, sudan rega. According to the author the word discount consisting of sati words is shorter and easier to remember than the word sudan rega which consists of two words because it is too long. Thus, code mixing by speakers is caused by the words in other languages used in speech are easier to remember and more stable in meaning.

\section{Pernicious homonimy}

Speech Context:

Doni imitates his mother when advising him who likes to play games.

Speech:

Doni: "Don, Don kon iku ben dina kok dolanan game wae."

(Don, Don, you play games every day)

(94/ 00.17.14/ YWB)

In the data utterance 94 there appears to be an external code mix in the form of words carried out by speakers. The word game has the equivalent word in the Javanese language, dolanan. If the speech of the speaker is changed into Javanese into "Don, Don kon iku ben dina why is dolanan dolanan wae." The word "dolanan" in the above utterances creates ambiguous meaning and is less clear / ambiguous because in the Javanese language the word dolanan has two meanings namely (1) play is a verb and (2) game is a noun. So it can be concluded by the author if the speaker uses words from his own language, the word can cause ambiguous meaning.

\section{Oversight}

Speech Context:

Doni shows Bayu the girl he is estimating.

Speech:

Doni: "Waduh, hihi, kuwi lho nyeraki arek wedok kayak ngono. Aku lho sing bando

pink."

(Wow, hihi, it's approaching a girl like that. I'm the pink headband)

(56/ 00.06.47/ YWB)

Doni is played by Joshua Suherman. Josua was born in Surabaya and lived and 
settled in Jakarta. The length of stay in Jakarta and the frequent use of Indonesian in communicating can cause a decrease in the vocabulary of the Javanese language that is owned, it could happen that speakers forget some vocabulary in Javanese.

In data 56, speakers can interfere with the external code in the form of pink words from English that insert into Javanese speech. In the speech of the speaker above, a pink word from English appears due to the limitations of the vocabulary owned by speakers.

\section{End (purpose and goal)}

Speech Context:

Bayu gave pecel orders for student council meetings.

Speech:

Bayu: "Ya udah ini jangan sampai berebut, didum ya."

'Ya sudah ini jangan sampai berebut, dibagi ya.'

(89/ 00.15.06/ YWB)

In the data 89, speakers are interfering with the internal code in the form of verbs from the Javanese language that enter the Indonesian language speech. Speakers interfered with the code because they wanted to explain and confirm that the pecel brought by the speaker was shared with students who were attending the Student Council meeting.

\section{Conclusion}

There are two types of code mixing, namely internal code mixing and external code mixing. Mix Java-Indonesian internal code (147 data), Indonesian-Javanese (8 data), while mixing Java-English external code (47 data), Java-Arabic (5 data), and Indonesian-English (14 data). The form of code mixing. Mix code in the form of 139 words, 23 data phrases, 43 data basters, 11 data redupilcations, and 5 data idioms. In Yowis Ben's film research, the most frequently mixed code appears is a mixture of codes from Indonesian that insert into Javanese sentences. The researcher suggests that through the Yowis Ben film, the audience is expected to be able to understand mixed code and add vocabulary to their vocabulary and this film can also be used as a teaching material in literary learning to improve the ability to analyze and appreciate drama and film texts.

\section{References}

Anjalia, Fuji. 2017. Analisis Campur Kode dalam Dialog Antartokoh pada Film Tjoet Nja’ Dhien. Dalam jurnal ilmiah mahasiswa PBSI .Vol. 2 No. 2, Maret: 142145.

Debbyansyah, Agung Tri. 2014. Campur Kode Bahasa Jawa dalam Bahasa Indonesia pada Film Jokowi. (Skripsi). Universitas Jember: Jember.

Hudha, Nurul. 2018. Alih Kode dan Campur Kode dalam Dialog Film Guru Bangsa Tjokroaminoto karya Gari Nugroho dan Implikasinya terhadap 
Pembelajaran Sosiolinguistik di Perguruan Tinggi. (Skripsi). Universitas Lampung: Bandar Lampung.

Mahsun. 2005. Metode Penelitian Bahasa. Jakarta: PT Raja Grafindo Persada.

Moleong, Lexy J. 2005. Metodologi Penelitian Kualitatif. Bandung: PT Remaja Rosdakarya.

Pratista, Himawan. 2008. Memahami Film. Jogjakarta : Homerian pustaka.

Puspita, Denti Okta. 2018. Campur Kode dalam Film My Stupid Bos dan Implikasinya pada Pembelajaran Bahasa Indonesia di SMA. (Skripsi). Universitas Lampung: Bandar Lampung.

Rohmadi, Muhammad, dkk. 2009. Morfologi, Telaah Morfem dan Kata. Surakarta: Yuma Pustaka.

Sutopo. 2002. Metodologi Penelitian Kualitatif. Surakarta: Sebelas Maret University Press.

Suwito. 1985. Pengantar Awal Sosiolinguistik Teori dan Problema. Surakarta: Henary Offset. 